\title{
Synthesis of Monolith Hydroxysodalite from Low Grade Kaolin and its Application as an Adsorbent for Lead
}

\author{
Khalid J. Aswad \\ Department of Geology \\ College of Science \\ Mosul University
}

\author{
Faraj H. Tobia \\ S.E. of Geological Survery \\ and Mining (GEOSURV), \\ Baghdad
}

(Received 23/5/2006, Accepted 5/4/2007)

\begin{abstract}
Low grade kaolin is converted to monolith hydroxysodalite dihydrate by hydrothermal treatment with $10 \mathrm{M} \mathrm{NaOH}$ solution i.e., higher $\mathrm{Na}$ concentration, $\mathrm{Na} / \mathrm{Si}$ $=1.3$. The $\mathrm{X}$-ray diffraction and infrared methods are used to determine the chemical formula of cured material which is $\mathrm{Na}_{8} \mathrm{Al}_{6} \mathrm{Si}_{6} \mathrm{O}_{24}(\mathrm{OH})_{2} \cdot 2 \mathrm{H}_{2} \mathrm{O}$. The CEC values do not correlate with that of SSA values, where for uncured kaolin the CEC have increased from 6.52 to $89.13 \mathrm{meq} / 100 \mathrm{~g}$ for the cured kaolin or synthetic hydroxysodalite; on the other hand, the SSA values have decreased from 87 to $10 \mathrm{~m}^{2} / \mathrm{g}$. An adsorption experiment shows that the expansion of the framework of hydroxysodalite is due to the replacement of $\mathrm{Na}^{+}$by $\mathrm{Pb}^{2+}$; moreover, about $91 \%$ of $\mathrm{Pb}$ is effectively removed. To get optimum removal, the solution must be buffered to about $\mathrm{pH}=4.5$.
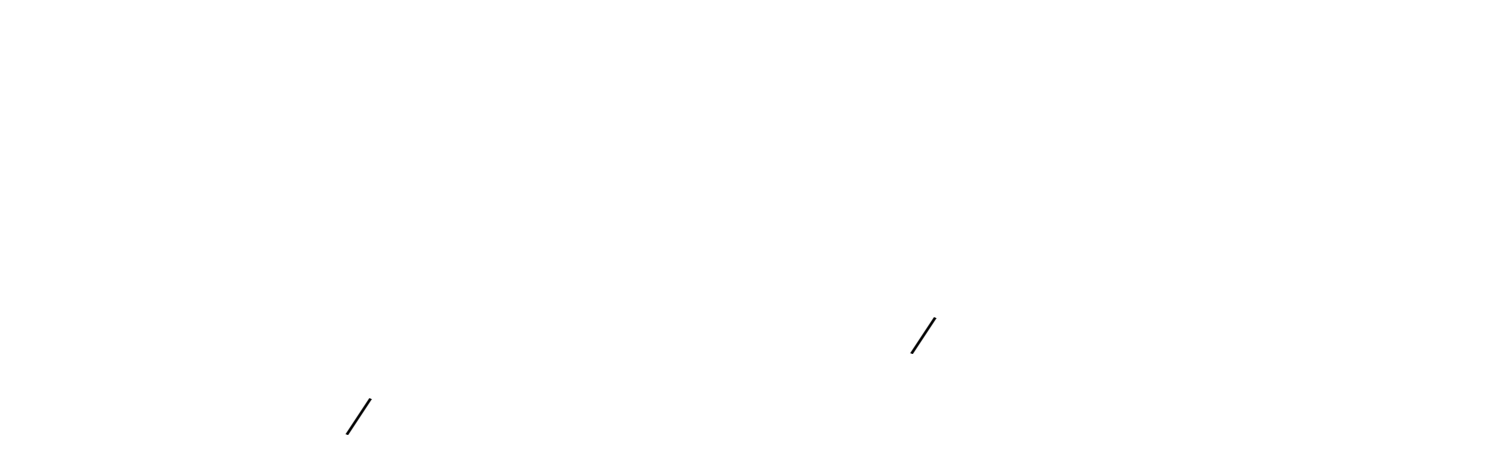

\author{
خالدجال لمuود \\ قصم علوم الارض لكالية العلوم \\ جلمعة الموصل
}

\section{المالخص}

مُ تحضير معن لحادي الطور من الهيدروكسيصودلايت ثنائي جزيئة الماء من المعالجة الحرمائية

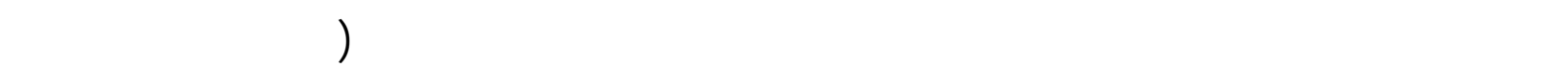

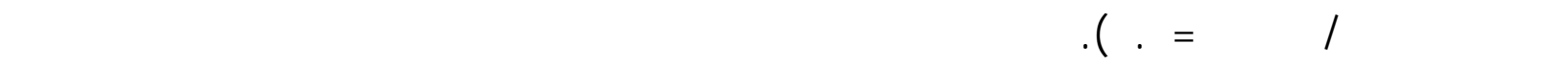

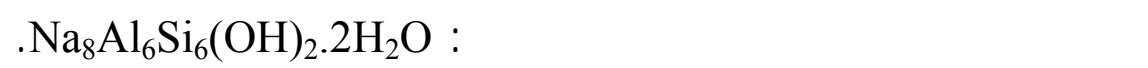

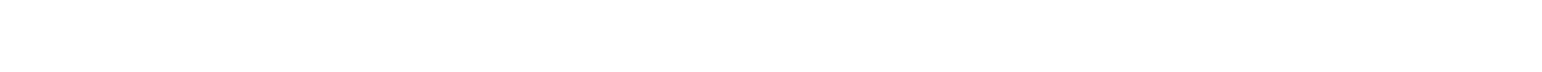

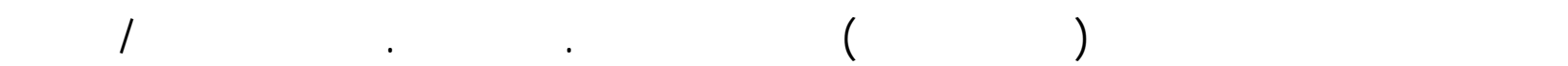

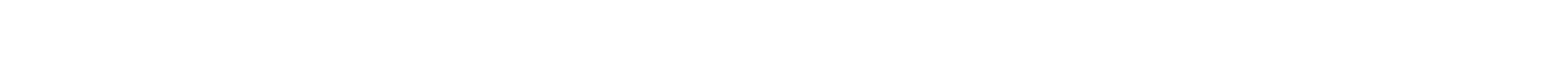

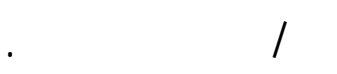


بينت تجارب الامتصاص ان تمدد الشبكة البنائية للهيدروكسيصودلايت هي بموجب لحلل ايون

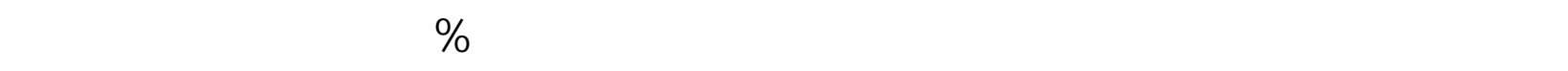
المحلول. لغرض الحصول على القيم المثل للازالة، يجب تظظيم درجة حلمضية المحلول اله حوالي

\section{INTRODUCTION}

Large quantities of low grade kaolin are available in Hussainiyat Formation/ western desert of Iraq (Fig. 1); and most of this kaolin is used for refractory industries. Kaolin is a ready source of $\mathrm{Al}$ and $\mathrm{Si}$ and is necessary for the synthesis of zeolites which are natural alumino-silicates with $\mathrm{SiO}_{2}$ and $\mathrm{Al}_{2} \mathrm{O}_{3}$ ratio near unity (Woolard et al., 2000; Hassan et al., 2002).

Zeolites including hydroxysodalite have a wide range of materials of both natural and synthetic origins. Generally, the crystalline alumino-silicates have a three dimensional framework in which silicon and aluminum atoms are tetrahedrally coordinated with oxygen atoms $\left(\mathrm{TO}_{4}\right.$ tetrahedra, $\left.\mathrm{T}=\mathrm{Al}, \mathrm{Si}\right)$, where each apical oxygen atom is shared with an adjacent tetrahedron (Hassan et al., 2002). Thus, the ratio $\mathrm{O} / \mathrm{T}$ always equals 2 (Woolard et al., 2000).

The three dimensional framework gives the zeolites some peculiar properties, e.g. adsorption and catalytic ion exchange reactions, and molecular sieving which find variety of industrial applications. Zeolites can exist either as minerals found in natural sediments, volcanic and metamorphic rocks or as synthetic materials made by hydrothermal synthesis (Bonaccorsi and Provebio, 2004). The synthesized materials have a superior retention ability for alkali, alkaline earth and heavy metal ions; they have also the ability to sequester ions in lattice positions or within their networks of channels and voids; as such they are nearly perfect waste forms, where, the zeolite can host alkali, alkaline earth and a variety of higher valance cations (Grutzeck, 1999, 2004). However, hydroxysodalite is more stable for common use than other zeolite under wider range of $\mathrm{pH}$ conditions. Vucinic et al. (2003) reported that pure hydroxysodalite can be formed at $\mathrm{Na}_{2} \mathrm{O} / \mathrm{SiO}_{2}=1$ and at low $\mathrm{H}_{2} \mathrm{O} / \mathrm{Na}_{2} \mathrm{O}$ ratio. It forms with sodalite octahydrate a binary system of $\mathrm{Na}_{6+x}\left(\mathrm{AlSiO}_{4}\right)_{6}(\mathrm{OH})_{\mathrm{x}} \cdot \mathrm{nH} \mathrm{H}_{2} \mathrm{O}$ composition with $0=\mathrm{x}=2$ and $0<\mathrm{n}<8$.

The aim of this work is to investigate conversions of low grade kaolin which is of considerable quantity to the more economically hydroxysodalite in Hussainiyat Formation in the Iraqi western desert. It also aims to determine the efficiency of the product to remove a high toxic metal, i.e. $\mathrm{Pb}$ in aqueous waste products.

\section{Hydroxysodalite Preparation:}

\section{EXPERIMENTAL ASPECT}

Hydroxysodalite products is prepared by using $10 \mathrm{~g}$ of Hussainiyat low grade kaolin powder $(65 \mu)$ which is added to $50 \mathrm{ml}$ of $10 \mathrm{M} \mathrm{NaOH}$ solution, and then heated to $150^{\circ} \mathrm{C}$ for $24 \mathrm{~h}$ in a teflon autoclave. The product is collected by filtration, washed with hot distilled water and dried at $80^{\circ} \mathrm{C}$ for $24 \mathrm{~h}$. 


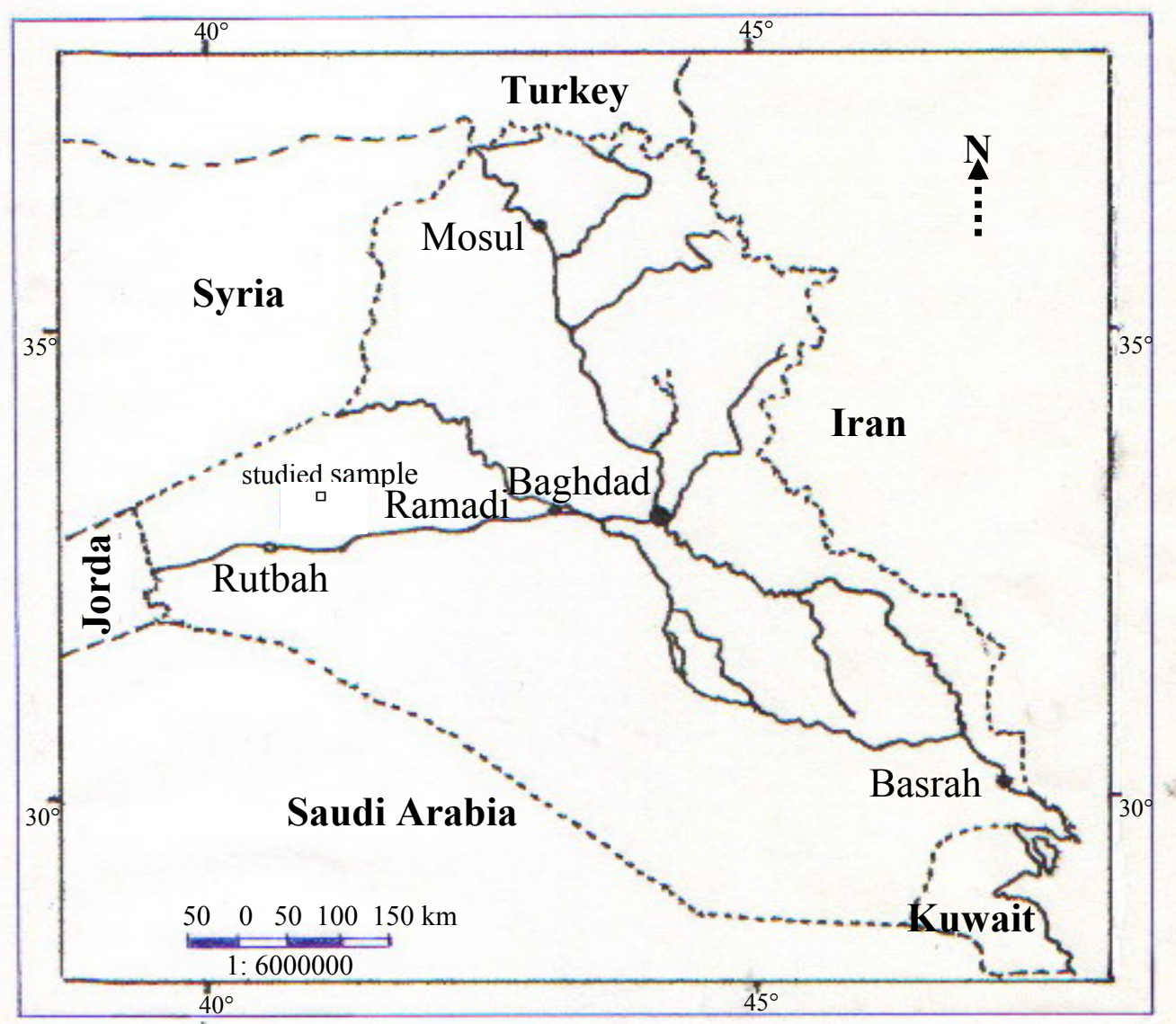

Fig. 1: Location of the studied sample, Hussainiyat Formation/ Iraqi western desert.

\section{X-Ray Diffraction (XRD):}

The collected samples are again washed with hot distilled water to remove any possible remaining $\mathrm{NaOH}$ prior to X-ray diffraction analysis. After drying, a diffraction pattern is obtained by using a Philips PW $1410 \mathrm{X}$-ray diffractometer; the apparatus is set at $40 \mathrm{kV}$ and $20 \mathrm{~mA}$ using $\mathrm{CuK} \alpha$ radiation $\left(\lambda=1.541 \mathrm{~A}^{\circ}\right)$. The JCPDS files are used to identify the resultant crystalline phase which is a monolithic hydroxysodalite (Fig. 2).

\section{Cation Exchange Capacity (CEC):}

CECs are determined following the procedure of Chapman (cited in Black et al.,1965). 4gms of low grade kaolin are shaken for $5 \mathrm{~min}$ with $33 \mathrm{ml}$ of $1 \mathrm{M}$ sodium acetate followed by centrifuging. The shaking and centrifuging, are repeated three times. The precipitate is then shaken for $5 \mathrm{~min}$ with $33 \mathrm{ml}$ of $50 \%$ ethanol three times for removing excess $\mathrm{Na}^{+}$. Replacement of $\mathrm{Na}^{+}$is then carried out with $\mathrm{NH}_{4}{ }^{+}$by shaking the precipitate three times with $33 \mathrm{ml}$ of $1 \mathrm{M}$ ammonium acetate. The sodium extracts are then collected, and analyzed for Na content by flame photometry using 410 Flame Photometer, provided by Sherwood Company.

\section{Specific Surface Area (SSA):}

SSA measurements are determined by using the procedure of Bower and Goertzen (1959 cited in Black et al., 1965). $5 \mathrm{gms}$ of the sample are treated with ethylene glycol (EG); the SSA is calculated using the following equation: 
$\mathrm{SSA}=\mathrm{W}_{\mathrm{g}} \cdot \mathrm{W}_{\mathrm{s}} / \mathbf{0 . 0 0 0 3 1} \quad$ where;

SSA: specific surface area $\left(\mathrm{m}^{2} / \mathrm{g}\right)$

$\mathrm{W}_{\mathrm{g}}$ : wt. of ethylene glycol (gm) used.

$\mathrm{W}_{\mathrm{s}}$ : wt. of the sample $(\mathrm{gm})$

0.00031: amount of EG adsorbed per $\mathrm{m}^{2}$

\section{Infrared Spectroscopy Study:}

The infrared transmission spectrum of the solid sample is obtained by the $\mathrm{KBr}$ method. The spectrum was recorded on a Beckmann model 4250 spectrometer in region of 300 to $1800 \mathrm{~cm}^{-1}$.

\section{Lead Adsorption Experiments:}

The adsorption (or substitution) of lead by synthetic hydroxysodalite was carried out at different $\mathrm{pH}$ values and $\mathrm{Pb}$ concentrations using $0.5 \mathrm{gm}$ of cured material, which was shaken with $100 \mathrm{ml}$ of 100,300 and $500 \mathrm{ppm}$ of $\mathrm{Pb}^{2+}$ solutions. After $24 \mathrm{~h}$, the solid precipitate was separated from the solution by filtration. The concentration of lead in the filtrates was then determined by using Perkin-Elmer 503 Atomic Absorption Spectrophotometer. However, adsorption (or substitution) was determined by the difference between the initial and the final concentration of lead in the filtrates.

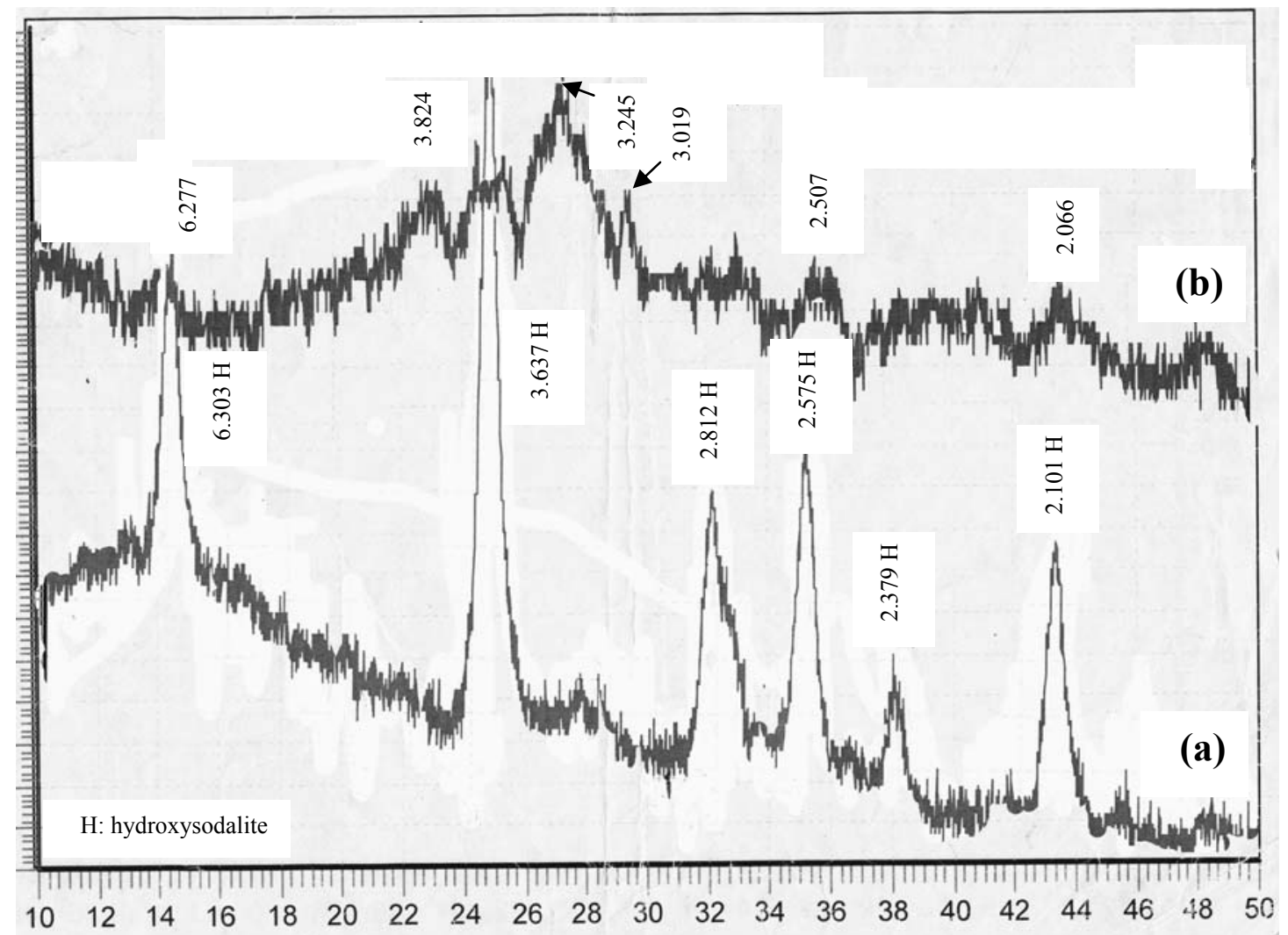

Fig. 2: XRD patterns of synthetic hydroxysodalite, (a) untreated hydroxysodalite (b) treated with $1000 \mathrm{ppm}$ of $\mathrm{Pb}^{2+}$ solution. 


\section{RESULTS AND DISCUSSION}

The chemical analysis of the kaolin used as the starting material (untreated) and the cured material (treated) are shown in table 1 . The mole ratios $\mathrm{Na} / \mathrm{Si}$ and $\mathrm{Si} / \mathrm{Al}$ for the cured material (prepared hydroxysodalite) are 1.318 and 1.031, respectively. The X-ray diffraction pattern for the hydrothermally treated kaolin is shown in Figure 2a. Only monolith phase of sodalite is identified at the most three intense peaks of (112), (110), and (114) reflections of d-spacing 3.629, 6.285 and 2.095 $\mathrm{A}^{\circ}$, respectively (Yamzin, 1978) as illustrated in table 2. According to the obtained chemical analysis (Table 1), X-ray diffraction and infrared data, the phase can be classified as hydroxysodalite dihydrate type of cubic system belonging to $\mathrm{P} 43 \mathrm{n}$ space group with the chemical formula of $\mathrm{Na}_{8} \mathrm{Al}_{6} \mathrm{Si}_{6} \mathrm{O}_{24}(\mathrm{OH})_{2} \cdot 2 \mathrm{H}_{2} \mathrm{O}$ and the $a$ lattice parameter is $8.903 \mathrm{~A}^{\circ}$. The latter is plotted on Figure 3 to confirm the final chemical formula for the synthetic phase. The predicted angle $\mathrm{Si}-\mathrm{O}-\mathrm{Al}$ is equal to $139.5^{\circ}\left(140-150^{\circ}\right.$ for zeolite).

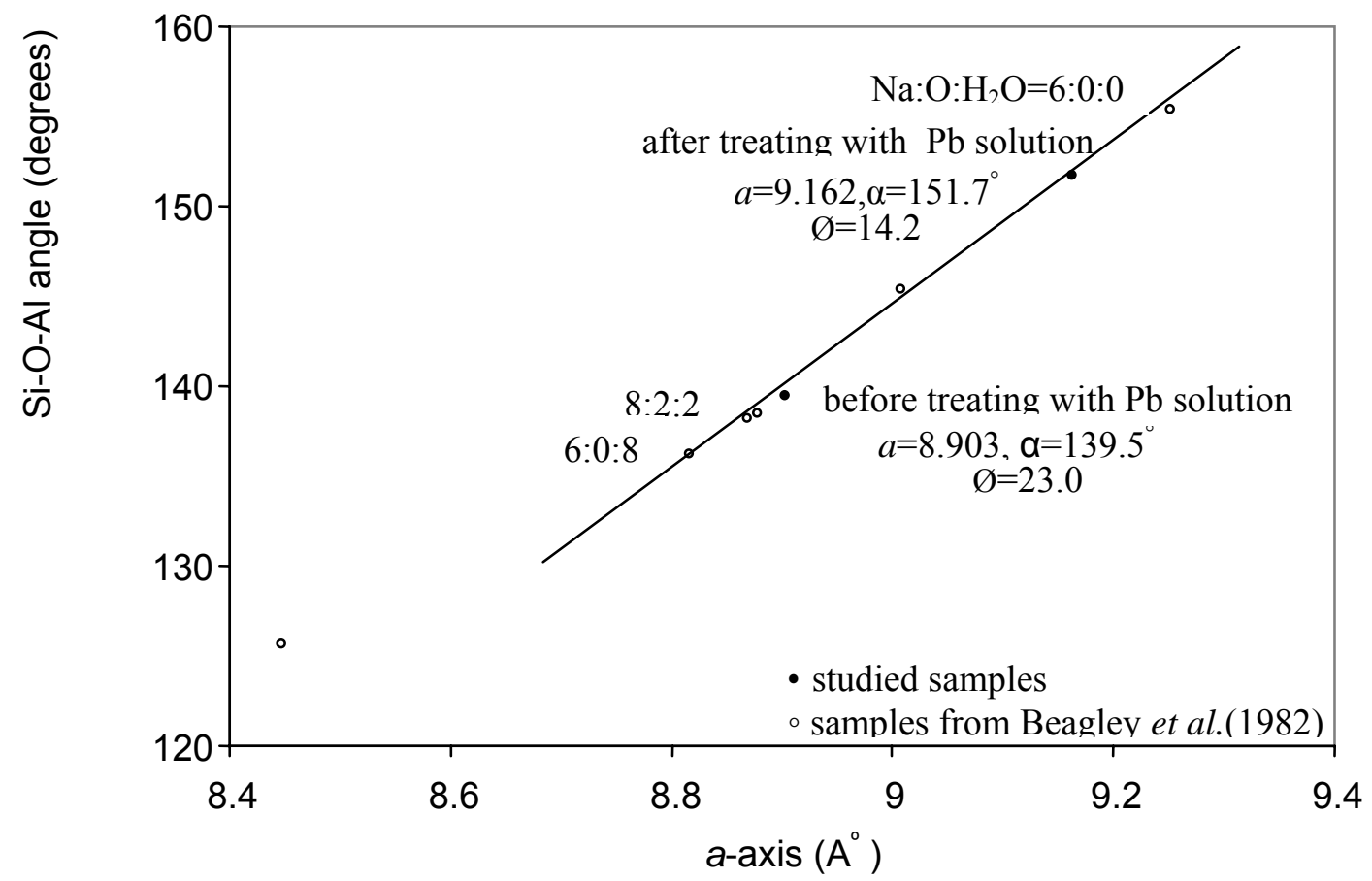

Fig. 3: Relationship between lattice parameter $a$ and Si-O-Al angle for different kinds of sodalite (based on Beagley et al., 1982; Aswad, in preparation) and studied hydroxysodalite. $\varnothing=$ the tilt angle in Figure 7 .

Table 1: Chemical analysis of low grade kaolin sample (untreated) and synthetic hydroxysodalite (treated).

\begin{tabular}{|c|c|c|c|c|c|c|c|c|c|c|}
\hline & \multicolumn{10}{|c|}{ Wt(\%) } \\
\hline & $\mathrm{SiO}_{2}$ & $\mathrm{Fe}_{2} \mathrm{O}_{3}$ & $\mathbf{A l}_{2} \mathbf{O}_{3}$ & $\mathrm{TiO}_{2}$ & $\mathrm{CaO}$ & $\begin{array}{c}\mathrm{Mg} \\
\mathrm{O}\end{array}$ & $\mathrm{Na}_{2} \mathrm{O}$ & $\mathrm{K}_{2} \mathrm{O}$ & L.O.I & $\begin{array}{c}\text { Tota } \\
\text { l }\end{array}$ \\
\hline untreated & $\begin{array}{l}\varepsilon^{\mu} . \text {. } \\
\varepsilon\end{array}$ & 1.0 & ro.rV & 1.10 & r & $\cdot \cdot V$ & · & $\cdot .1$. & س & $\begin{array}{l}95.8 \\
5\end{array}$ \\
\hline treated & $\begin{array}{l}\mu \mu . \Lambda \\
r\end{array}$ & $\cdot . \Lambda r$ & rV.Ar & nil & nil & $\cdot .7$ & 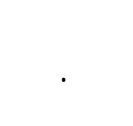 & $\cdot .1 \mu$ & II. & $\begin{array}{l}97.0 \\
3\end{array}$ \\
\hline
\end{tabular}


A systematic investigation has been carried out in the $300-1800 \mathrm{~cm}^{-1}$ region, since it contains the fundamental vibrations of $\mathrm{TO}_{4}$ tetrahedra. Interpretations of these spectra are based on the assignment of the infrared bands to certain structural groups in the various zeolite frameworks. Hence, this method is complementary to x-ray analysis. The infrared spectrum of the obtained zeolitic material is a result of the new crystal phase vibrations (Fig. 4). The band between 950- $1250 \mathrm{~cm}^{-1}$ confirms the tetrahedral coordination of aluminum in the zeolite framework. This band is the main asymmetric stretching vibration of the tetrahedra, the frequency of which decreases with increasing amount of $\mathrm{Al}$ in the tetrahedral sites of the alumino-silicate framework of the zeolite (Araujo et al., 1999; Vucinic et al..2003).

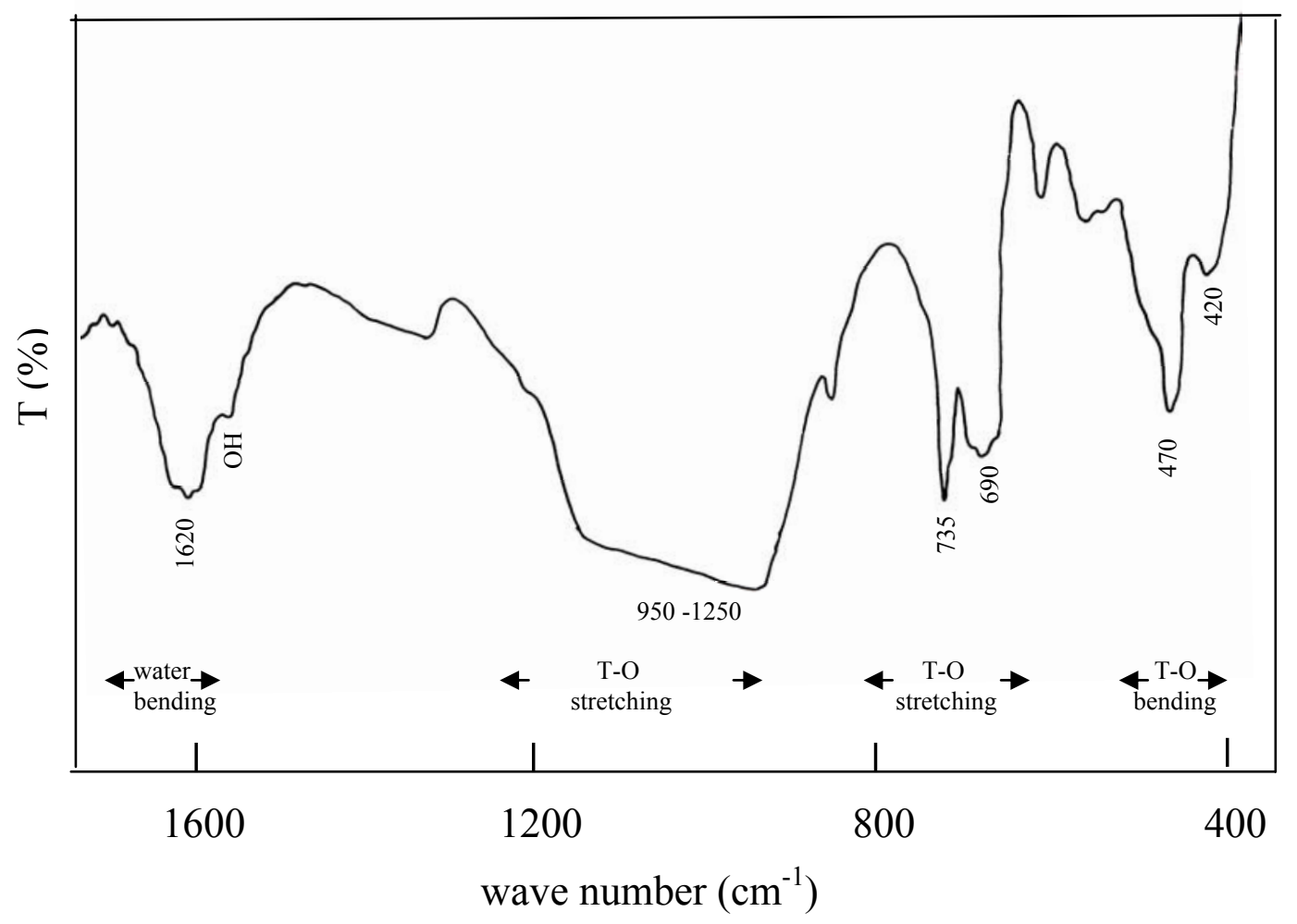

Fig. 4: Adsorption infrared spectrum of the prepared hydroxysodalite.

Table 2: Miller indices (hkl) and d-spacing reported by Yamzin (1978) and the present study for prepared hydroxysodalite.

\begin{tabular}{|c|c|c|c|c|}
\hline \multirow[t]{2}{*}{ hkl } & \multicolumn{2}{|c|}{ (Yamzin,1978) } & \multicolumn{2}{|c|}{ (present study) } \\
\hline & d-published & intensity & d- observed & intensity \\
\hline 111 & r.7rq & $1 \cdots$ & r. $7 \mu$ & $1 \cdots$ \\
\hline 11. & 7. $\wedge \wedge 0$ & 07.77 & ר. ${ }^{\mu} \cdot \mu$ & $\varepsilon \Lambda . \cdot \mu$ \\
\hline $11 \varepsilon$ & $r .90$ & HV.rE & $r .1 \cdot 1$ & $\varepsilon \cdot . \vee q$ \\
\hline זY & $r .077$ & rา. . & r.ovo & EV.r \\
\hline
\end{tabular}




\begin{tabular}{|c|c|c|c|c|}
\hline . וץ . & r.AII & 19. & r.sir & $\varepsilon \cdot . \vee q$ \\
\hline וץץ & r.rVר & $17 . \wedge 7$ & r.rvq & ro... \\
\hline
\end{tabular}

Moreover, the shoulder in the $1150-1200 \mathrm{~cm}^{-1}$ region in the pure zeolite spectra is the result of asymmetric stretching vibrations of external linkages of primary structural units. The band $470 \mathrm{~cm}^{-1}$ is assigned to T-O bending mode. Stretching modes involving mainly the tetrahedral atoms are assigned in the region of $650-820 \mathrm{~cm}^{-1}$ (Araujo et al., 1999); these are sensitive to the Si-Al composition of the framework and may shift to a lower frequency with increasing number of tetrahedral Al atoms. The presence of the band at $1620 \mathrm{~cm}^{-1}$ (stretching vibration) is attributed to the both water and hydroxyl ion $(\mathrm{OH})$ of hydroxysodalite.

Table 3 shows the cation exchange capacity and specific surface area of the low grade kaolin and the synthetic hydroxysodalite. The CEC values do not correlate with that of SSA values. The CEC for synthetic hydroxysodalite (prepared) is much higher than the unconverted kaolin but lower than those obtained by Chang and Shih (1998) ( 151 to $186 \mathrm{meq} / 100 \mathrm{~g}$ ) and the maximum of $300 \mathrm{meq} / 100 \mathrm{~g}$ observed by Woolard et al. (2000). However, cation exchange capacity for hydroxysodalite which is restricted to room temperature may lead to low values (Singer and Bertgaut, 1995).

Table 3: Cation exchange capacity and specific surface area for low grade kaolin (untreated) and synthetic hydroxysodalite (treated).

\begin{tabular}{|c|c|c|}
\hline & SSA $\left(\mathrm{m}^{2} / \mathrm{g}\right)$ & CEC (meq $/ \mathbf{1 0 0 g})$ \\
\hline untreated & $\wedge \mathrm{V}$ & $7.0 \mathrm{r}$ \\
\hline treated & $1 \cdot$ & $\wedge 9.1 \mathrm{r}$ \\
\hline
\end{tabular}

The rather high specific surface area of low grade kaolin compared with that of synthetic hydroxysodalite may be due to the kind of organic material (ethylene glycol) used in the measurement, which may prevent the molecules from penetrating the voids and channels, leading to lower values of SSA.

Table 4 and Figure 5 illustrate the relationship between $\mathrm{Pb}^{2+}$ and $\mathrm{pH}$ of the solutions before and after treatment with the hydroxysodalite. Figure 5 indicates that cured (treated) kaolin has the greatest affinity for lead at $\mathrm{pH}=4.5$. The ion exchange study were carried out without $\mathrm{pH}$ control in order to avoid the addition of a competing exchangeable cation. Table 4 shows the initial $\mathrm{pH}$ decreases with increasing of $\mathrm{Pb}$ concentration. The $\mathrm{pH}$ increases about twice after $24 \mathrm{~h}$. The higher percent of $\mathrm{Pb}$ exchange $(91.2 \%)$ was at $100 \mathrm{ppm}$ of $\mathrm{Pb}$ concentration in solution where $\mathrm{pH}$ is the higher (3.5).

The shape of the isotherms in Figure 6 suggests that the adsorption (substitution) behavior could be modeled by using the Langmuir isotherm.

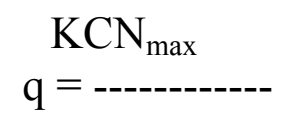

( Woolard et al., 2000) 
where:

$\mathrm{q}$ : the amount per gram of solid $\mathrm{Pb}$ adsorbed

$\mathrm{Pb}$ in solution at equilibrium $\mathrm{IC}$ : the concentration of

$\mathrm{K}$ : the Langmuir adsorption constant

$\mathrm{N}_{\text {max }}$ : the total number of sites available for adsorption on the solid surface. Moreover, figure 6 illustrates the adsorption behavior of various modified samples which are $\mathrm{pH}$ dependent. It is obvious that in all cases the percentage of adsorbed lead increases as $\mathrm{pH}$ increases. This is likely to be via an ion-exchange mechanism, where the $\mathrm{Pb}^{2+}$ cations replace $\mathrm{H}^{+}$ions in the zeolite structure (Woolard et al., 2000):

$$
\equiv \mathrm{Z}-\mathrm{H}+\mathrm{Pb}^{2+} \equiv \mathrm{Z}-\mathrm{Pb}^{2+}+\mathrm{H}^{+}
$$

where $\equiv Z$ - represent an exchange site in the zeolite framework. Furthermore the $\mathrm{pH}$ of the experiment does not exceed (6) because figure 6 contains a curve for the theoretical precipitation of amorphous $\mathrm{Pb}(\mathrm{OH})_{2}$. This curve was based on the MINEQL+ program (Schecher and McAvoy, 1991 in Woolard et al., 2000) and in this study is included to determine whether the ion exchange of $\mathrm{Pb}$ has been taken place rather than adsorption. Figure 6 shows that the $\mathrm{Pb}$ is effectively removed by hydroxysodalite at $\mathrm{pH}<5$

Table 4: Concentrations of added, resident and exchanged lead in the solutions and $\mathrm{pH}$ values before and after treatment.

\begin{tabular}{|c|c|c|c|c|c|c|}
\hline & $\begin{array}{c}\text { Pb conc. in } \\
\text { solution } \\
(\mathrm{ppm}) / \mathrm{log} \\
\left(\mathrm{C}_{0 \mathrm{AA}}\right)\end{array}$ & $\begin{array}{c}\text { initial pH of } \\
\qquad\left(C_{0 A}\right)\end{array}$ & $\begin{array}{l}\text { pH after } \\
24 h \text { of } C_{A}\end{array}$ & $\begin{array}{c}(\mathrm{ppm}) / \mathrm{log} \\
\left(\mathrm{C}_{\mathrm{A}}\right)\end{array}$ & $\begin{array}{l}(\mathrm{ppm}) / \mathrm{log} \\
\left(\mathrm{C}_{\mathrm{oA}}-\mathrm{C}_{\mathrm{A}}\right)\end{array}$ & $\begin{array}{c}P b \\
\text { exchanged } \\
\%\end{array}$ \\
\hline & $100 / 2.000$ & 1.0. & r.o. & $8.8 / 0.944$ & $91.2 / 1.960$ & $91 . r$ \\
\hline & $300 / 2.477$ & 1.1. & r.E. & $105 / 2.021$ & $195 / 2.290$ & 70. \\
\hline & $500 / 2.699$ & .90 & r... & $288 / 2.460$ & $42.4 / 1.627$ & $\varepsilon r . \varepsilon$ \\
\hline
\end{tabular}

$\mathrm{C}_{\mathrm{oA}}=$ Initial concentration of $\mathrm{A}$ ( $\mathrm{Pb}$ cation).

$\mathrm{C}_{\mathrm{A}}=$ Equilibrium concentration of $\mathrm{A}$.

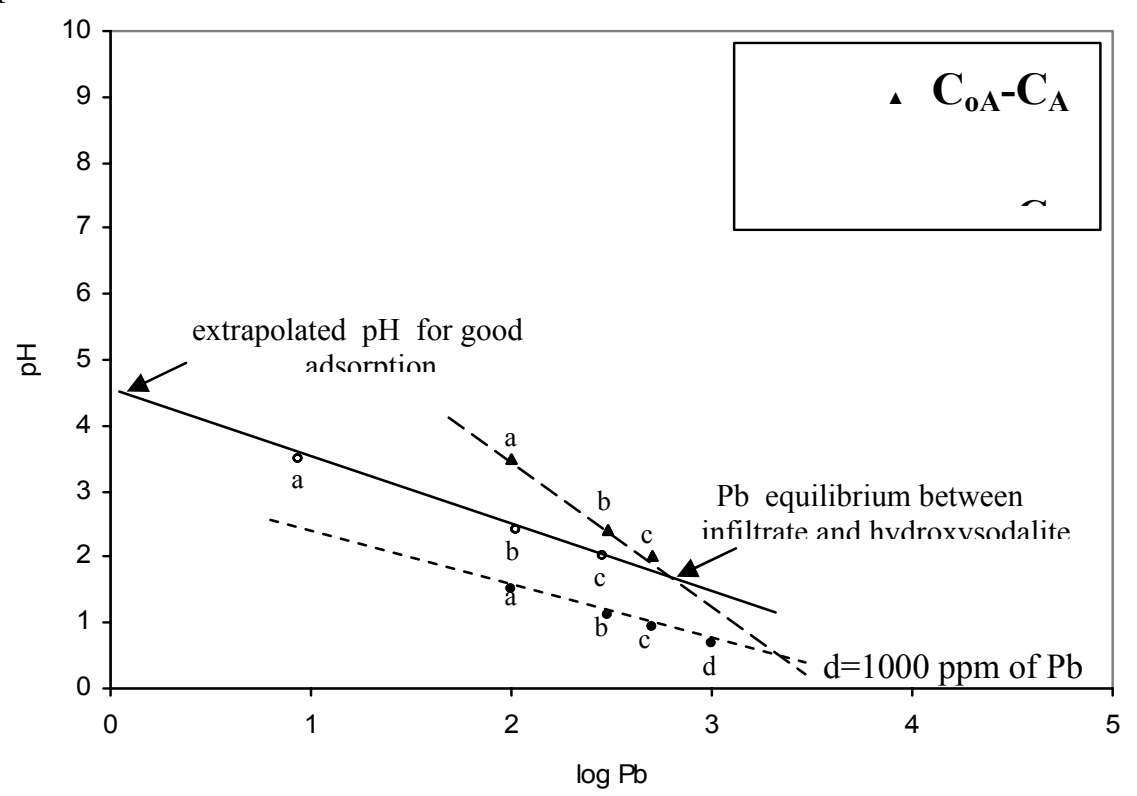


Fig. 5: Relationship between $\mathrm{pH}$ and $\mathrm{Pb}$ concentration, and the condition of good adsorption (substitution). Data from Table 4.

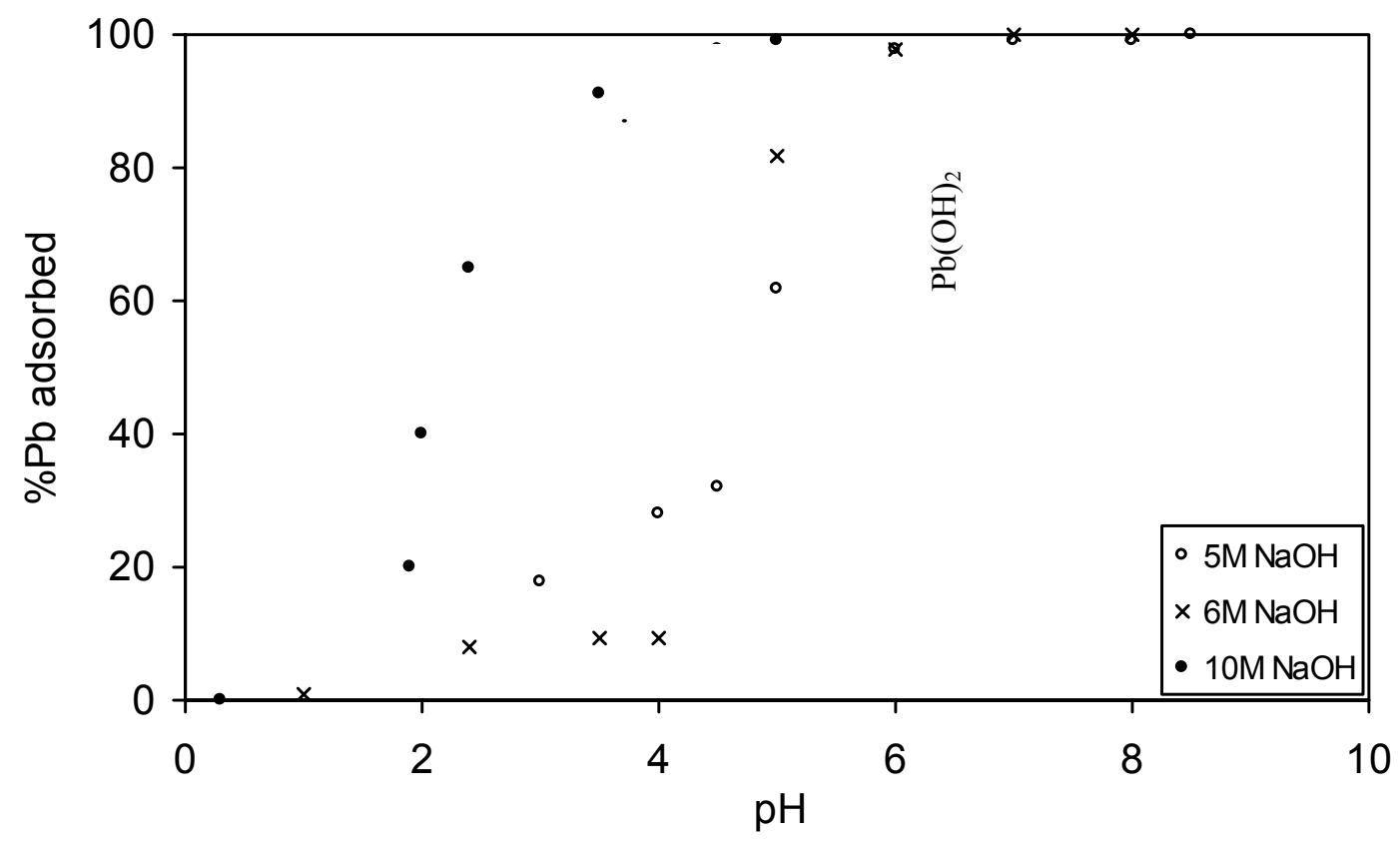

Fig. 6: Adsorption edges for the adsorption of $\mathrm{Pb}$ onto different treated samples as a function of $\mathrm{pH}\left(5 \mathrm{M}, 6 \mathrm{M} \mathrm{NaOH}\right.$ and $\mathrm{Pb}(\mathrm{OH})_{2}$ from Woolard et al., 2000, and 10M NaOH for this study presented in table 4).

The study of XRD patterns of $\mathrm{Pb}$ treated hydroxysodalite (Figure 2b) with 1000 ppm of $\mathrm{Pb}^{2+}\left(\right.$ as $\left.\mathrm{PbCl}_{2}\right)$ shows shifting in the pattern and broadening of the peaks and a little increase in the background because of the emission. This may be due to the replacement of $\mathrm{Pb}^{2+}$ for $\mathrm{H}^{+}$. It could also be attributed to the fact that the lead has higher scattering coefficient compared with sodium (about 7.5 times).

Consequently, this accounts for the difference in d-spacing and relative integrated intensity; but the crystal system is still cubic. The lattice parameter $a$ expanded from $8.903 \mathrm{~A}^{\circ}$ to $9.162 \mathrm{~A}^{\circ}$; this means that the framework of the phase has a partially collapsed structure. However, it becomes nearly fully expanded structure (Figure 7) after treating it with $\mathrm{Pb}^{2+}$ solution. Figure 3 also shows clearly that the tilt angle $\varnothing$ decreases (from $23.0^{\circ}$ to $14.2^{\circ}$ ) and the $\mathrm{Si}-\mathrm{O}-\mathrm{Al}$ angle $(\alpha)$ increases (from $139.5^{\circ}$ to $151.7^{\circ}$ ) due to the cavity ion increase in size $\left(\mathrm{Na}^{+}=0.93 \mathrm{~A}^{\circ}, \mathrm{Pb}^{2+}=1.20 \mathrm{~A}^{\circ}\right)$.

The measured equilibrium data are plotted as ion exchange isotherm (Figure 8) reporting the equivalent fraction of the in-going cation $\mathrm{A}$ in the solid phase $\left(\mathrm{X}_{\mathrm{AZ}}\right)$ as a function of the equivalent fraction of the same cation in solution $\left(\mathrm{X}_{\mathrm{AS}}\right)$. The isotherm data were calculated by:

$$
\mathrm{X}_{\mathrm{AS}}=\mathrm{C}_{\mathrm{A}} / \mathrm{C}_{\mathrm{oA}} \text { and } \mathrm{X}_{\mathrm{AZ}}=\left(\mathrm{C}_{\mathrm{oA}}-\mathrm{C}_{\mathrm{A}}\right) / \mathrm{CEC}_{\mathrm{mz}} \quad \text { (de Barros et al.,2002) }
$$


Where; $\mathrm{C}_{\mathrm{A}}$ stands for the equilibrium concentration of cation $\mathrm{A}$ in the solution phase; $\mathrm{C}_{\mathrm{oA}}$ stands for the initial concentration of $\mathrm{A}$ (Table 4) and $\mathrm{CEC}_{\mathrm{mz}}$ is the cation exchange capacity of the hydroxysodalite (Table 3 ).

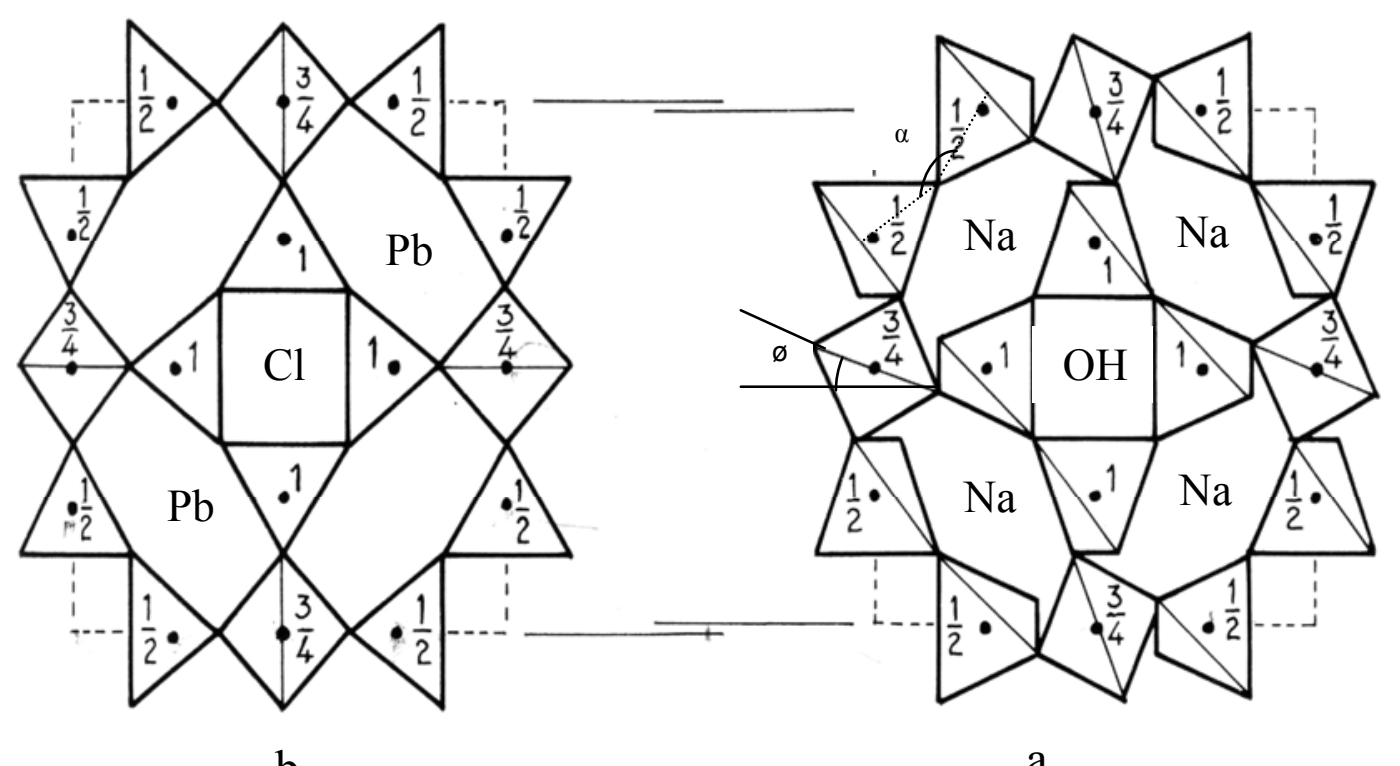

b

a

Fig. 7: Schematic diagrams for the partially-collapsed (a) and fully- expanded structure (b) of sodalite (modified after Taylor, 1972).

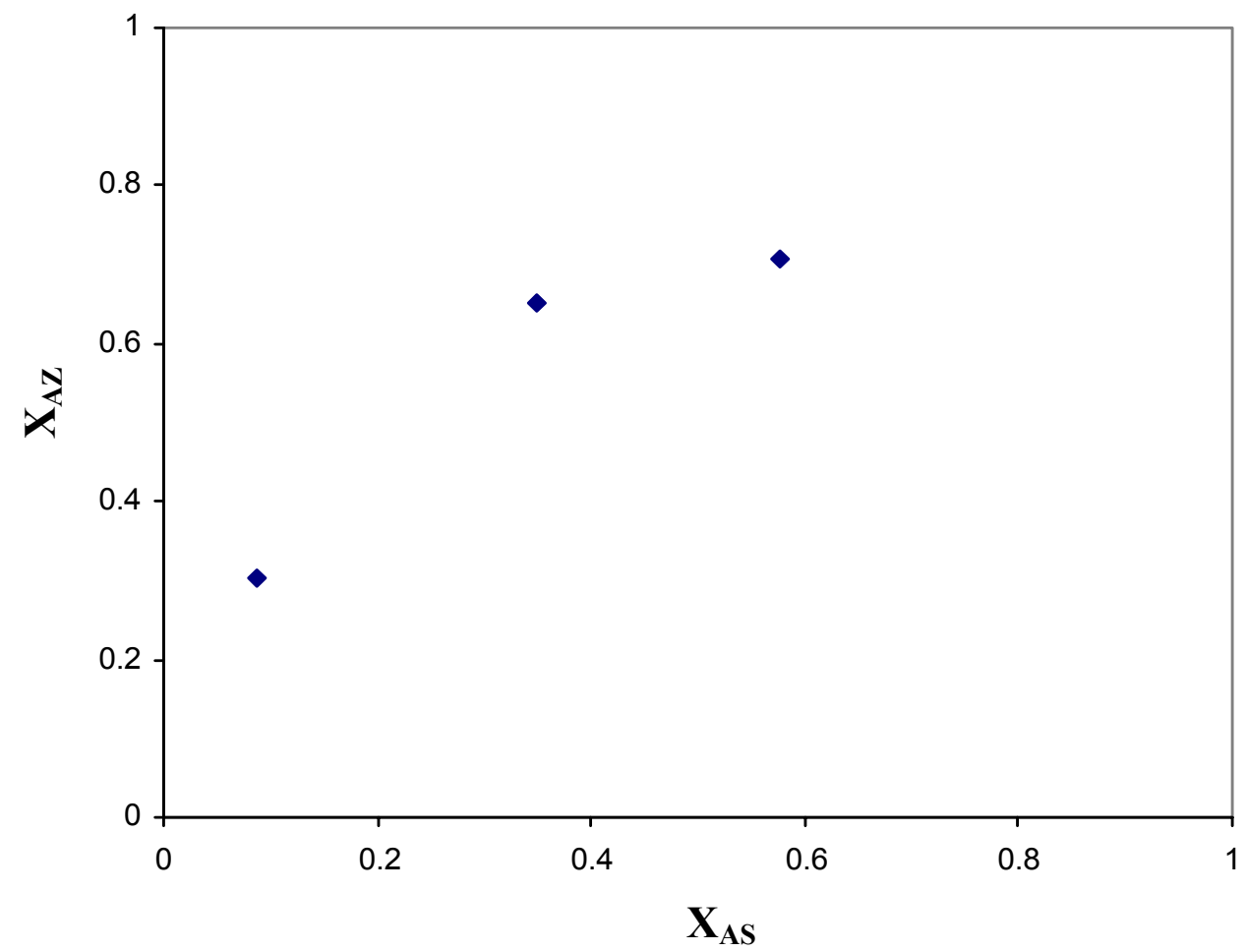


Fig. 8: Lead exchange isotherm on prepared hydroxysodalite.

This isotherm shows convexly upward curvature, because the hydroxysodalite is more selective towards the in-going cation $\mathrm{A}(\mathrm{Pb})$. The ion exchange isotherm shown in Figure 8 (the isotherm is failed to completion) is terminated slightly in value at about $70 \%$ which is related to the full occupancy of the $\beta$-cage. Therefore, it may be concluded that although the hydroxysodalite is very selective to $\mathrm{Pb}$ ions, the progress of exchange is limited by the diffusion of the large hydrated cation $\mathrm{Pb}$ through the cage apertures.

\section{CONCLUSIONS}

The hydrothermal treatment of low grade kaolin by high alkaline solutions with $\mathrm{Na} / \mathrm{Si}$ mole ratio $=1.3$ results in a monolithic hydroxysodalite dihydrate which has been examined by $\mathrm{X}$-ray diffraction and infrared spectra with the formula of $\mathrm{Na}_{8} \mathrm{Al}_{6} \mathrm{Si}_{6} \mathrm{O}_{24}(\mathrm{OH})_{2} \cdot 2 \mathrm{H}_{2} \mathrm{O}$. The resultant modified kaolin or synthetic hydroxysodalite has a greater cation exchange capacity and lower specific surface area than the untreated kaolin.

The synthetic hydroxysodalite shows a greater adsorption (as substitution in the cages) of lead bearing solutions, in which about $91 \%$ of $\mathrm{Pb}$ is effectively removed at $\mathrm{pH}=3.5$. Finally, the study shows that the $\mathrm{Pb}$ removal is $\mathrm{pH}$ dependant, and the efficiency of $\mathrm{Pb}$ removal from the solution increases as $\mathrm{pH}$ increases. Hence, to get optimum $\mathrm{Pb}$ removal the solution must be $\mathrm{pH}$ buffered, this might add a competing exchangeable cation provided by the buffering solution. Hydroxysodalite, however, could be used as alkaline internal buffer.

\section{REFERENCES}

Araujo,de,L.R.G., Cavalcante,Jr,C.L., Farias,K.M., Guedes,I., Sasaki,J.M., Freire, P.T.C., Melo,F.E.A. and Mendes-Filho,J.(1999) Synthesis of cubic Y zeolite using a pulsed microwave heating system, Minerals Research,Vol.2, No.2, pp.105-109.

Beagley,B., Henderson,C.M.B. and Taylor,D.(1982) The crystal structures of aluminosilicate-sodolite: X-ray diffraction studies and computer modeling, Mineralogical Magazine,Vol.46, pp.459-464.

Black,C.A., Evans,D.D., White,J.L., Ensminger,L.E. and Clark,F.E.(1965) Methods of soil analysis, chemical and microbiological properties, Part 2, Amer. Soc. of Agronomy, USA, 1571p.

Bonaccorsi,L. and Proverbio,E.( 2004) Hydrothermal synthesis of zeolite LTA by microwave irradiation, Mat. Res. Innovat., Vol.8, No.1, pp.53-57.

Chang,H.L. and Shih,W.H.( 1998) A general method for the conversion of fly ash into zeolites as ion exchangers for cesium, Ind. Eng. Chem.Res., Vol.37, pp.71-78. de Barros,M.A., Zola,A.S., Arroyo,P.A., Sousa-Aguiar,E.F. and Tavares,C.R. (2002) Equilibrium and ion exchange studies of $\mathrm{Cr}^{3+}$ on zeolites $\mathrm{NaA}$ and NaX, Maringa, Vol. 24, No. 6, pp. 1619-1625. 
Grutzeck,M.( 2004) Physical, chemical and structural evolution of zeolite- containing waste forms produced from metakiolinite and calcined HLW, Env. Manag. Sci. Program, Project no.65366.

Hassan,M.S., Ismail,I.S. and Ibrahim,I.A.(2002) Synthesis of zeolite Al Na from low grade Kalabsha kaolin, Erzmetall, Vol 55, No.9.

Singer,A. and Berkgaut,V.(1995) Cation exchange properties of hydrother- mally treated coal fly ash, Envi. Sci. Tech., Vol.29, pp.1748-1753 .

Vucinic,D., Miljanovic,I., Rosic,A. and Lazic P.( 2003) Effect of $\mathrm{Na}_{2} \mathrm{O} / \mathrm{SiO}_{2}$ mole ratio on the crystal type of zeolite synthesized from coal fly ash, $J$. Serb. Chem. Soc., Vol.68, No.6, pp.471-478.

Woolard,C.D., Petrus,K. and Horst,M.(2000) The use of modified fly ash as an adsorbent for lead, Water S.A., Vol.26, No.4, pp.53-536.

Yamzin,E.A.(1978) Kristallogr., Soviet Physc. Cryst., Vol.23, pp.27-29. 